\title{
Demonstrating an integrated pest management strategy in forage- and seed-brassica crops using a collaborative approach
}

\author{
Abie Horrocks ${ }^{1, \star}$, Paul A. Horne ${ }^{2}$ and Melanie M. Davidson ${ }^{3}$ \\ ${ }^{1}$ Foundation for Arable Research, PO Box 23133, Hornby 8441, New Zealand \\ ${ }^{2} I P M$ Technologies Pty Ltd, PO Box 560, Hurstbridge, Victoria 3099, Australia \\ ${ }^{3}$ The New Zealand Institute for Plant \& Food Research Limited, Private Bag 4704, Christchurch \\ 8140, New Zealand \\ *Corresponding author: Abie.Horrocks@far.org.nz
}

\begin{abstract}
An integrated pest management (IPM) strategy was compared with farmers' conventional pest management practices on twelve spring- and autumn-sown seed and forage brassica crops. Demonstration trials were conducted in Canterbury from spring 2015 to autumn 2017 by splitting farmers' paddocks in half and applying the two management approaches side by side. A farmer participatory approach was used, with management decisions based on monitoring pests and biological-control agents. Farmer and adviser training with a focus on monitoring and identification was carried out. Biological-control agents capable of contributing to pest control were identified in all brassica crops. There was a 35\% reduction in the number of insecticides applied under IPM compared with conventional management, negligible crop yield differences, and the type of insecticides applied was different. IPM adoption at these farms was high by the end of the 3-year project with 11 of the 12 farmers implementing IPM across $90-100 \%$ of their brassica crops. This project was a starting point for an industry-wide change of practice to IPM, which has become more widespread since its completion.
\end{abstract}

Keywords Practice change, adoption, participatory research, biological-control agents, brassica, arable, beneficial predators, IPM.

\section{INTRODUCTION}

Integrated pest management (IPM) is a strategy for managing pest problems using biological (e.g. predators, parasitoids, pathogens; referred to in this paper as biological-control agents), cultural (e.g. farm management practices) and chemical (e.g. selective insecticides) methods in a compatible way that minimises economic, health and environmental risks (Alston \& Reding 1998). Management decisions are based on trends in the ratios of pests:biological-control agents throughout the growing season, obtained through monitoring. It is an approach to pest control that aims to maximise the use of biological- control agents, while using insecticides in the least disruptive way and only when necessary (Kogan 1998; Horne \& Page 2008).

Forage brassicas occupy the largest area of cultivated land in New Zealand, with around 400,000 hectares grown annually. Seed brassicas are also an important arable crop although they cover a smaller area. Key pests affecting the establishment of seed and forage brassica crops in Canterbury include slugs (several species), wheat bug (Nysius huttoni; referred to as Nysius hereafter), and two species of springtails (Sminthurus viridis and Bourlietella hortensis). As the crop matures, key foliar pests 
include diamondback moth caterpillars (Plutella xylostella), cabbage white butterfly caterpillars (Pieris rapae), aphids (mainly Brevicoryne brassicae) and leaf-mining fly (Scaptomyza flava) (de Ruiter et al. 2009; Walker et al. 2016).

Successful IPM programmes for vegetable brassicas (Walker et al. 2009; Walker et al. 2016) do exist but pest management in forage and seed brassica crops in New Zealand has historically relied on broad-spectrum insecticides. This is despite: often-hidden potential costs; resurgence of primary pests; upsurges of secondary pests; killing of non-target fauna (including biologicalcontrol agents); and wider adverse environmental impacts. Using an insecticide-only strategy also risks accelerating the onset of insecticide resistance to the products used (Perkins \& Patterson 1997; Kogan 1998; Devine \& Furlong 2007).

European Union legislation has recently banned the use of many broad-spectrum insecticides (Abrol \& Shankar 2012) and there may well be pressure in other regions to follow suit. This issue is particularly important for exporters who may need to adhere to restrictions on insecticides required in the importing country, rather than the country of origin. Additionally, global trends are driving an increase in development of compounds with a more selective, or narrow, range of activity (i.e. non-toxic to vertebrates, or toxic to a specific groups of invertebrates). However, the use of any insecticide (broad-spectrum or selective) can result in the development of resistance to insecticides (Abrol \& Shankar 2012). Additionally, even if an insecticide is selective (and therefore considered IPM compatible), it does not, in most cases, entirely eliminate all effects on the full range of biological-control agents. Such complexities associated with using any insecticide highlight the critical value of monitoring both pests and biologicalcontrol agents to eliminate unnecessary routine insecticide applications. Lewis et al. (1997) noted that therapeutic tools should only be used as secondary backups, otherwise overreliance on them will result in an IPM approach that differs only from the conventional approach in the selection of products used.

Transient biological-control agents only establish in a crop if there are hosts or prey present to eat or parasitise. Important naturally occurring transient biological-control agents in brassicas include ladybirds (Adalia bipunctata, Coccinella septempunctata), brown lacewings (Micromus tasmaniae), black and orange hoverflies (Melangyna novaezelandiae and Melanostoma fasciatum respectively) and parasitoid wasps (Hymenoptera: mainly Diadegma semiclausum and Aphidius spp.).

There are a range of benefits of IPM over conventional management yet the change to using the IPM approach is often slow (Horne \& Page 2011). In many cases, the catalysts for making the change to IPM occur when there is a crisis in pest control. That is, either the insecticides that have been relied upon stop working (insecticide resistance) or the insecticide is no longer available (registration is withdrawn or the product is withdrawn by the manufacturer from sale) (Horne \& Page 2011). There are, however, a number of circumstances where farmers are more naturally responsive to embracing a different management approach and it is entirely possible to have farmers understand and implement IPM without a particular crisis. The key factors to success were welldocumented by Herbert Jr (1995) and involve the collaborative and participatory approach of working with individuals or small groups of farmers and providing expert, site-specific advice when required (Horne \& Page 2008; Horne \& Page 2011). A Ministry for Primary Industries' funded Sustainable Farming Fund project entitled: 'IPM strategy development and demonstration for forage and seed brassicas' was set up to demonstrate to collaborating farmers and industry representatives an IPM strategy compared with a traditional insecticide approach to manage brassica pests. The purpose of the study was to use farmer participatory trials to: (i) determine if biological-control agents that could help reduce pest populations were present in brassica crops (if not disrupted by broad- 
spectrum insecticides); (ii) demonstrate to farmers that adoption of IPM practices would result in fewer insecticides without yield losses due to unacceptable pest levels; and (iii) test the applicability of a participatory framework to influence adoption of IPM practices.

\section{MATERIALS AND METHODS}

The project was carried out with 12 farmers (and their advisers) in Canterbury, New Zealand. Seed and forage brassica sites were chosen across a range of farming systems (dairy support, sheep and beef and arable) and were sown and harvested across a range of dates (Table 1). Management of twelve spring- and autumn-sown seed and forage brassica crops was split to compare pest control using IPM to the farmers' current pest management (Conventional). All 'Conventional' sites used some broad-spectrum insecticides at times when they would be disruptive to key beneficial species. If any such products were used on 'IPM' sites, then they were applied at times when they would cause minimal disruption. Over 3 years (spring 2015 to autumn 2017), monitoring was carried out in the two autumn- sown seed crops, three spring-sown seed crops and seven spring/summer-sown forage crops (Table 1) every 2-4 weeks, depending on the time of season.

All 12 farmers agreed to follow two strict IPM parameters for decision making on the IPM-managed side. Firstly, insecticides and molluscicides would be applied only if results of monitoring the ratio of pests:biological-control agents throughout the growing season indicated they were needed (i.e. no routine application of insecticides) and secondly only selective IPM compatible insecticides were used (unless none were available). Farmers were trained to use simple monitoring techniques to identify pests and biological-control agents and were involved in the monitoring and decision making as much as possible. Pest:biological-control agent ratios were used to inform decision making on the IPM side as there are limitations to using thresholds in an IPM system. For example, if, hypothetically, there are 10 aphids and no biological-control agents then a different decision is required than if there are 10 aphids and 8 biological-control

Table 1 Farm type, location, crops and sowing and harvest dates of brassica crops used to compare conventional and integrated pest management strategies for pest control. Sth $=$ South, Nth $=$ North. The area of paddocks ranged from 10-17 hectares.

\begin{tabular}{|c|c|c|c|c|c|}
\hline Farm type & $\begin{array}{c}\text { Year } \\
\text { harvested }\end{array}$ & Location & Crop & Sowing date & $\begin{array}{l}\text { Harvest/grazing } \\
\text { date }\end{array}$ \\
\hline \#1 Arable & One & Sth Canterbury & $\begin{array}{l}\text { Chinese } \\
\text { Cabbage-seed }\end{array}$ & September 2014 & February 2015 \\
\hline \#2 Sheep and beef & One & Nth Canterbury & Kale-forage & November 2014 & June 2015 \\
\hline \#3 Dairy support & One & Nth Canterbury & Kale-forage & September 2014 & June 2015 \\
\hline \#4 Arable & Two & Mid-Canterbury & $\begin{array}{l}\text { HTT turnip- } \\
\text { seed }\end{array}$ & April 2015 & December 2015 \\
\hline \#5 Arable & Two & & Radish-seed & & March 2016 \\
\hline \#6 Dairy support & Two & Mid-Canterbury & Kale-forage & December 2015 & May 2016 \\
\hline \#7 Sheep and beef & Two & Mid-Canterbury & Kale-forage & December 2015 & April 2016 \\
\hline \#8 Arable & Two & Mid-Canterbury & Kale-forage & December 2016 & April 2017 \\
\hline \#9 Arable & Three & Mid-Canterbury & Turnip-seed & April 2016 & December 2016 \\
\hline \#10 Arable & Three & Mid-Canterbury & Radish-seed & October 2016 & March 2017 \\
\hline \#11 Arable & Three & Mid-Canterbury & Kale-forage & October 2016 & January 2017 \\
\hline \#12 Arable & Three & Mid-Canterbury & Kale-forage & November 2016 & May 2017 \\
\hline
\end{tabular}


agents. All farmers adhered to the IPM decision parameters but, due to the lack of rigid thresholds, there was a degree of subjectivity in deciding whether an IPM compatible spray was required as it came down to the farmers' own experience and their perception of risk. Each farmer was encouraged to develop guidelines to suit their experience levels and circumstances. Field visits and workshops were an important part of the project so the farmers involved and IPM experts could disseminate key messages to other farmers, advisers and industry representatives.

\section{Monitoring}

On average monitoring at each paddock was carried out every 2 weeks. Slugs (several species) were monitored using direct searching and plywood tiles (three 29 × $29 \mathrm{~cm}$ tiles placed within the paddock). A yellow sticky trap mounted on a $60-\mathrm{cm}$ bamboo stake was installed next to the first slug tile to give an indication of diamondback moths, winged aphids and aphid predators and parasitoid wasps present within the crop.

Once the crop had emerged, direct visual searches were carried out for caterpillars (diamondback moth, white butterfly), aphids, Nysius, springtails and leaf miner. Feeding damage or the presence of predators (such as ladybirds, brown lacewings, black and orange hoverflies) was recorded. Sweep netting was also carried out on both the IPM and conventional sites (approximately eight sweeps over 10 $\mathrm{m}$ distance, repeated 3-5 times). All insect identification was carried out in the field, with the farmer and/or their adviser where possible.

\section{Yields and insecticide use}

Records were kept of all insecticide and molluscicide applications. Yield was estimated at the end of the crop (at harvest or grazing) by using yield-monitoring equipment in the combine harvesters if available. However, farmer perceptions of the success and practicability of the approach were the main criteria for success.

\section{Survey}

All 12 farmers were surveyed at the end of their involvement in the project. The survey asked a range of questions (Table 2) to determine if they had changed their approach towards the management of pests in their brassica crops as a result of the project.

\section{Statistical method}

The responses to the survey by growers of forage crops were compared to responses of seedcrop growers using a two-sample t-test. Where a broad-spectrum insecticide was applied to only the conventional side, the total number of biological-control agents on the conventional and IPM sides for the following two monitoring dates were also compared using a two-sample t-test.

\section{RESULTS AND DISCUSSION \\ Insecticide use and transient biological- control agents}

Across the five paddocks containing seed crops, an average of 3.4 sprays were used on the conventionally managed side compared to 2.2 on the IPM managed side. Across the seven paddocks containing forage crops, an average of 1.9 sprays were used under conventional management compared to 1.2 under IPM (Table $3)$.

There was a $35 \%$ reduction in the total amount of insecticides used on the IPM side compared to the conventional side and this was consistent for seed- and forage-brassica crops. On average across both seed and forage brassicas, $75 \%$ of the insecticides used on the IPM plots were selective compared to only $35 \%$ on the conventional system, where the majority of insecticides used were broad-spectrum.

Transient biological-control agents such as lacewings, ladybirds and parasitoid wasps were found to be naturally occurring in the forageand seed-brassica paddocks. Broad-spectrum insecticides were applied to the conventional side of nine paddocks when nothing was applied to the IPM side (Table 2) at various stages of the trial. In these instances, there were significantly 
Table 2 Survey questions 12 farmers were asked on completion of the project and responses partitioned by seed and forage crops.

\begin{tabular}{ll}
\hline $\begin{array}{l}\text { Question } \\
\text { number }\end{array}$ & Question \\
\hline $1 . \quad$ & $\begin{array}{l}\text { Do you now have a greater } \\
\text { understanding of the role } \\
\text { biological control agents can } \\
\text { play in contributing to pest } \\
\text { control in your brassica crops? }\end{array}$
\end{tabular}

2. Are you more confident recognising biological control agents in your brassica crops?
Multiple choice options and answers ( $\%$ Forage (F) $n=7$; response) Seed (S) $n=5$;
Total $n=12$.

Yes (100). $\quad F=7, S=5$

No.

Yes (75). $\quad F=7, S=2$

No, but would expect adviser to offer

this service (25).

$S=3$

No, this is unlikely to be a

consideration.

3. When you or your adviser monitor your brassica crops are you now looking for pests and biological control agents or just pests?

4. After being involved in the project would you now prefer/ expect advisers on your farm to be able to offer IPM compatible advice in your brassica crops?

Both pests and biological control agents $\mathrm{F}=7, \mathrm{~S}=5$ (100).

Main focus is still on pests.

I would prefer they had this expertise $\quad \mathrm{F}=6, \mathrm{~S}=4$ (83).

I expect them to have this expertise (17).

$$
\mathrm{F}=1, \mathrm{~S}=1
$$

No, this is not a preference or expectation.

5. Has your choice of chemicals changed since involvement in the project?

No, selectivity of the insecticides was

$\mathrm{F}=1, \mathrm{~S}=1$ already an important consideration (17). Yes, selectivity of the insecticides is now an important consideration (83).

$F=6, S=4$

No, price remains the most important consideration.

6. Have you continued using

Yes (100)

$\mathrm{F}=7, \mathrm{~S}=5$

IPM in any of your brassica

No.

project?

7. If the answer to the previous question was yes, what $\%$ of your brassica crops are you managing with IPM?

$100 \%$

$90-100 \%(92)$

$70-90$

$F=7, S=4$

$<70 \%(8)$

$S=1$

$100 \%(92)$

$90-100 \%(8)$

$\mathrm{F}=7, \mathrm{~S}=4$

In the next 5 years what $\%$ of your brassica crops do you

70-90 IPM? 
more biological-control agents on the IPM side in the two monitoring events after insecticide application ( $\mathrm{P}=0.009$, Fig. 1). There were no observable yield differences at any of the sites so it is probable that the biological-control agents were able to provide a similar degree of control to the broad-spectrum insecticides.

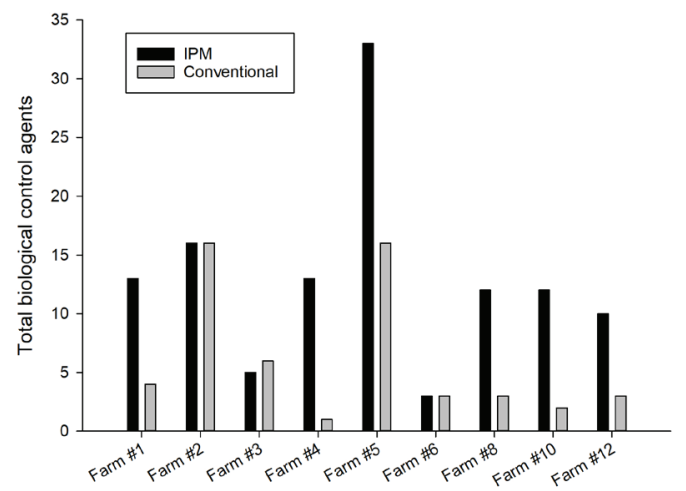

Figure 1 Total number of predators (lacewings, ladybirds and hoverflies) and parasitoid wasps recorded on the conventional and integrated pest management (IPM) sides for the two monitoring dates after broad-spectrum insecticides had been applied to the conventional side only on nine farms.

\section{Survey results and the collaborative approach}

The responses of the participating farmers to the questionnaire provided are shown in Table 3.

A common response was that the farmers had not realised how many biological control agents are present on their farm helping them control the pests "for free". Eleven of the 12 farmers were implementing IPM across $90-100 \%$ of their brassica crops by the end of the 3 years. All 12 of the farmers said they would not go back to assessing pest pressure without considering biological control agents. All the growers of forage crops indicated they had a better understanding of biological control agents, would be able to recognise and monitor for them or expect the crop scouts to do so, and would apply IPM to the whole farm within the next 5 years. Seed crop growers were slightly more conservative in their response to the survey questions $(\mathrm{F}=8.47$, $\mathrm{P}<0.001)$. All growers of seed crops responded that they had a better understanding of biological control agents and would choose insecticides that were compatible with biological control agents but they were less confident in being able to identify them (Table 3).

This project was able to reach around 500 additional farmers and advisors through (18 field days and workshops that were held as part of the project. However, the most important result was further uptake by industry. In particular, key agronomy and chemical companies organised further field days and training events that were beyond the scope of the research project.

An increase in the adoption of IPM strategies in forage and seed brassicas, such as those outlined here, could significantly improve the financial and environmental performance of these crops. This project demonstrated not only to farmers but to advisors and the agrochemical industry that IPM offers a practical and highly cost-effective method of controlling insect pests. As a result, there is growing interest from farmers wanting to adopt improved pest management practices and agronomists wanting to offer a wider range of services to their clients.

Post-project communication with reseller agronomists and some sectors of the chemical industry has reinforced that the aim of the project aligned well with industry purpose. In particular, using IPM can add value to the service they provide and promote the use of IPM compatible products used within an IPM pest management approach to ensure that they are not overused. This project has successfully initiated ongoing farmer and advisor interest, uptake and a fundamental change to how agronomists look at crops, make decisions and on what insecticides they advise to be used (if any). 
Table 3 Insecticides and molluscicides used on the integrated pest management (IPM) and conventionally managed crops for the 12 monitored paddocks. Insecticides in bold are considered disruptive to key biological control agents in most circumstances

\begin{tabular}{|c|c|c|c|}
\hline Farm & Date & Conventional & IPM \\
\hline \#1 Arable & $\begin{array}{l}2 \text { Dec. } 2014 \\
4 \text { Jan. } 2015 \\
13 \text { Jan. } 2015\end{array}$ & $\begin{array}{l}\text { Ampligo }^{\circledast}(100 \mathrm{~mL} / \mathrm{ha}) \\
\text { Pirimor }^{\circledast}(160 \mathrm{~g} / \mathrm{ha}) \\
\text { Exirel }^{\oplus}(100 \mathrm{~mL} / \mathrm{ha})\end{array}$ & $\begin{array}{l}\text { - } \\
\text { Pirimor }(160 \mathrm{~g} / \mathrm{ha}) \\
\text { Exirel }(100 \mathrm{~mL} / \mathrm{ha})\end{array}$ \\
\hline \#2 Sheep and beef & $\begin{array}{l}7 \text { Nov. } 2014 \\
27 \text { Dec. } 2014 \\
9 \text { Jan. } 2015 \\
18 \text { Feb. } 2015\end{array}$ & $\begin{array}{l}\text { Lorsban }^{\circledast}(1 \mathrm{~L} / \mathrm{ha}) \\
\text { Lorsban }(1 \mathrm{~L} / \mathrm{ha}) \\
\text { Exirel }(160 \mathrm{~mL} / \mathrm{ha}) \\
\text { Ampligo }(100 \mathrm{~mL} / \mathrm{ha})\end{array}$ & $\begin{array}{l}\text { Delfin }{ }^{\oplus}(0.5 \mathrm{~kg} / \mathrm{ha} \text { with Nufilm sticker }) \\
\text { Exirel }(160 \mathrm{~mL} / \mathrm{ha}) \\
\text { - }\end{array}$ \\
\hline \#3 Dairy support & $\begin{array}{l}17 \text { Nov. } 2014 \\
16 \text { Jan. } 2014 \\
6 \text { Feb. } 2015\end{array}$ & $\begin{array}{l}\text { Lorsban }^{\circledast}(1.25 \mathrm{~L} / \mathrm{ha}) \\
\text { Attack (1 L/ha) } \\
\text { Attack (1 L/ha) }\end{array}$ & $\begin{array}{l}\text { - } \\
\text { Delfin }(0.5 \mathrm{~kg} / \mathrm{ha} \text { with Nufilm sticker }) \\
\text { Delfin, } 0.5 \mathrm{~kg} / \text { ha with Nufilm sticker })\end{array}$ \\
\hline \#4 Arable & $\begin{array}{l}20 \text { Apr. } 2015 \\
15 \text { Jun. } 2015 \\
2 \text { Oct. } 2015 \\
20 \text { Nov. } 2015\end{array}$ & $\begin{array}{l}\text { Suscon Green } \\
\text { Attack }(800 \mathrm{~mL} / \mathrm{ha}) \\
\text { Ampligo }(100 \mathrm{~L} / \mathrm{ha} \\
\text { Pirimor }(160 \mathrm{~g} / \mathrm{ha}) \text { and } \\
\text { Exirel }(250 \mathrm{~mL} / \mathrm{ha})\end{array}$ & $\begin{array}{l}\text { Suscon Green } \\
- \\
- \\
\text { Pirimor (160 g/ha) and Exirel (250 } \\
\text { mL/ha) }\end{array}$ \\
\hline \#5 Arable & $\begin{array}{l}6 \text { Oct. } 2015 \\
2 \text { Nov. } 2015\end{array}$ & $\begin{array}{l}\text { Lorsban }(1.5 \mathrm{~L} / \mathrm{ha}) \\
\text { Ampligo }(100 \mathrm{~mL} / \mathrm{ha})\end{array}$ & $\begin{array}{l}\text { Exirel (160 mL/ha) } \\
\text { - }\end{array}$ \\
\hline \#6 Dairy support & $\begin{array}{l}6 \text { Oct. } 2015 \\
2 \text { Nov. } 2015\end{array}$ & $\begin{array}{l}\text { Lorsban (1.25 L/ha) } \\
\text { Exirel (150 mL/ha) }\end{array}$ & Exirel $(150 \mathrm{~mL} / \mathrm{ha})$ \\
\hline \#7 Sheep and beef & $\begin{array}{l}7 \text { Dec. } 2016 \\
20 \text { Feb. } 2016\end{array}$ & $\begin{array}{l}\text { Lorsban (1.25 L/ha) } \\
\text { Exirel (150 mL/ha) }\end{array}$ & $\begin{array}{l}\text { Lorsban (1.25 L/ha) } \\
\text { Exirel (150 mL/ha) }\end{array}$ \\
\hline \#8 Arable & $\begin{array}{l}5 \text { Dec. } 2015 \\
7 \text { Jan. } 2016 \\
\text { 22 Jan. } 2016 \\
3 \text { Mar. } 2016\end{array}$ & 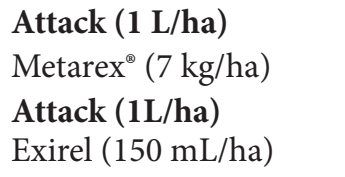 & $\begin{array}{l}\text { Attack (1L/ha) } \\
\text { Metarex }(7 \mathrm{~kg} / \mathrm{ha}) \\
- \\
\text { Exirel }(150 \mathrm{~mL} / \mathrm{ha})\end{array}$ \\
\hline \#9 Arable & $\begin{array}{l}\text { April } 2016 \\
\text { June } 2016 \\
\text { Sept. } 2016 \\
\text { Sept. } 2016\end{array}$ & $\begin{array}{l}\text { Lorsban }(1.5 \mathrm{~L} / \mathrm{ha}) \\
\text { Exirel }(150 \mathrm{~mL} / \mathrm{ha}) \\
\text { Transform }(75 \mathrm{~mL} / \mathrm{ha}) \\
\text { Exirel }(150 \mathrm{~mL} / \mathrm{ha})\end{array}$ & $\begin{array}{l}\text { Lorsban }(1.5 \mathrm{~L} / \mathrm{ha}) \\
\text { Exirel }(150 \mathrm{~mL} / \mathrm{ha}) \\
- \\
\text { Exirel }(150 \mathrm{~mL} / \mathrm{ha})\end{array}$ \\
\hline \#10 Arable & $\begin{array}{l}\text { Oct. } 2016 \\
\text { Nov. } 2016 \\
\text { Dec. } 2016\end{array}$ & $\begin{array}{l}\text { Phorate }(5 \mathbf{~ k g} / \mathbf{h a}) \\
\text { Karate }^{\circledast}(30 \mathrm{~mL} / \mathrm{ha}) \\
\text { Exirel }(150 \mathrm{~mL} / \mathrm{ha})\end{array}$ & $\begin{array}{l}\text { Phorate }(5 \mathrm{~kg} / \mathrm{ha}) \\
- \\
\text { Exirel }(150 \mathrm{~mL} / \mathrm{ha})\end{array}$ \\
\hline \#11 Arable & & - & - \\
\hline \#12 Arable & Dec. 2016 & Attack $(800 \mathrm{~mL} / \mathrm{ha})$ & - \\
\hline
\end{tabular}

Active ingredients (in parentheses) of listed products are: Ampligo (lambda-cyhalothrin and chlorantraniliprole, Syngenta, Switzerland); Attack ${ }^{\circledast}$ (pirimiphos-methyl and permethrin, Nufarm, USA); Delfin ${ }^{\circledast}$ (Bacillus thuringiensis var kurstaki, Certis, USA); Exirel ${ }^{\circledR}$ (cyantraniliprole, DuPont TM, USA); LorsbanTM (chlorpyrifos, Dow AgroSciences, USA); Karate (lambda-cyhalothrin, Syngenta, Switzerland); Metarex ${ }^{\circledast}$ (metaldehyde, De Sangosse SA, France); Phorate (phorate, Nufarm, USA); Pirimor ${ }^{\circledR}$ (pirimicarb, Syngenta, Switzerland), Suscon ${ }^{\circledR}$ Green (chlorpyrifos, Nufarm, USA); TransformTM (sulfoxaflor, Dow AgroSciences, USA). 


\section{CONCLUSION}

The participatory approach used here meant farmers had support from IPM experts as well as industry investment in IPM as a way of ensuring selective products are not overused, which could accelerate the development of resistance. As collaborating famers learnt more about the biological, cultural and selective chemical management options available they became increasingly reluctant to use broad-spectrum insecticides. It is important to note that their previous pest-control practice was to apply broad-spectrum insecticides that are relatively inexpensive. This change in attitude likely removes a substantial barrier to adoption of IPM strategies. Importantly, field-based support and education led to farmers embracing IPM in the absence of a crisis. This project was a starting point for an industry-wide change of practice to IPM, which has become more widespread throughout the industry since its completion.

\section{ACKNOWLEDGEMENTS}

Research was completed and funded under the Ministry for Primary Industries Sustainable Farming Fund project 401488 - IPM strategy development and demonstration for forage and seed brassicas, with co-funding from the Foundation for Arable Research, Forage Innovations and DuPont. Thanks go to The New Zealand Institute for Plant \& Food Research Limited for managing the project; Paul and Janet Horne from IPM Technologies Pty Ltd, Australia, for providing valuable expertise to the project; and most importantly all the farmers and advisers involved in the project over its duration.

\section{REFERENCES}

Abrol DP, Shankar U 2012. History, overview and principles of ecologically based pest management. In: Abrol DP, Shnkar U eds. Integrated Pest Management: Principles and Practice. In: CABI. Pp. 1-26.

Alston DG, Reding ME 1998. Factors influencing adoption and educational outreach of integrated pest management. Journal of
Extension 36: 1-8.

Chambers R, Sunderland K, Wyatt I, Vickerman $G$ 1983. The effects of predator exclusion and caging on cereal aphids in winter wheat. Journal of Applied Ecology 20: 209-224.

de Ruiter J, Wilson D, Maley S, Fletcher A, Fraser T, Scott W, Berryman S, Dumbleton A, Nichol W 2009. Management practices for forage brassicas. Forage Brassica Development Group. Plant \& Food Research, Auckland, New Zealand. https://www.dairynz.co.nz/ media/443169/management_practices_ forage_brassicas.pdf

Devine GJ, Furlong MJ 2007. Insecticide use: contexts and ecological consequences. Agriculture and Human Values 24: 281-306.

Edwards CA, Sunderland K, George K 1979. Studies on polyphagous predators of cereal aphids. Journal of Applied Ecology 16: 811823.

Herbert Jr D 1995. Integrated pest management systems: back to basics to overcome adoption obstacles. Journal of Agricultural Entomology 12: 203-210.

Horne P, Page J 2008. Integrated Pest Management for Crops and Pastures, Landlinks Press, CSIRO Publishing, Victoria, Australia.

Horne PA, Page J 2011. Changing to Minimal Reliance on Pesticides. In: Stoytcheva M ed. Pesticides in the Modern World. https:// www.intechopen.com/books/pesticidesin-the-modern-world-pesticides-use-andmanagement/changing-to-minimal-relianceon-pesticides. Pp. 337-345

Kogan M 1998. Integrated pest management: historical perspectives and contemporary developments. Annual Review of Entomology 43: 243-270.

Lewis WJ, Van Lenteren J, Phatak SC, Tumlinson J 1997. A total system approach to sustainable pest management. Proceedings of the National Academy of Sciences 94: 1224312248.

Perkins J, Patterson B 1997. Pests, pesticides and the environment: a historical perspective on the prospects for pesticide reduction. In: Pimentel D. ed. Techniques for Reducing 
Pesticide Use. John Wiley \& Sons. Chichester, UK. Pp. 13-33.

Van der Sluijs J, Amaral-Rogers V, Belzunces L, van Lexmond $\mathrm{MB}$, Bonmatin J-M, Chagnon M, Downs C, Furlan L, Gibbons D, Giorio C 2015. Conclusions of the Worldwide Integrated Assessment on the risks of neonicotinoids and fipronil to biodiversity and ecosystem functioning. Environmental Science and Pollution Research 22: 148-154.

Walker G, Wright P, Cameron P, Fletcher J, Berry N 2009. Information guide for integrated pest management in vegetable brassicas. Plant \& Food Research, Auckland, New Zealand.

Walker G, Wright P, Cameron P, Fletcher J, Walker M, Bulman S, Berry N 2016. Pests, natural enemies, diseases and disorders for vegetable brassicas in New Zealand. Plant \& Food Research, Auckland, New Zealand. https://www.freshvegetables.co.nz/assets/ J005621-handbook-brassica-final-medres. pdf 